\title{
Video Planet: A Teaching Case On The Detection Of Fraudulent Financial Reporting
}

Jeffrey Decker, University of Illinois at Springfield

Tim Kizirian, (Email: tkizirian@csuchico.edu), California State University, Chico

Lou X. Orchard, Wichita State University

\begin{abstract}
This paper presents a teaching case intended for use in an undergraduate auditing or fraud class. In the case, readers encounter an audit client, Video Planet, Inc., which exhibits many of the symptoms of companies that have been found to engage in fraudulent financial reporting. The case is intended to develop students' skills at detecting and interpreting warning signs of fraudulent financial reporting. Section One presents the facts of the case. Section Two presents decisionguiding questions. Section Three provides teaching notes. Section Four provides a summary of the paper.
\end{abstract}

\section{CASE FACTS}

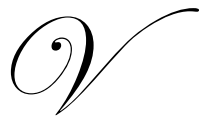

ideo Planet, Inc. (VPI) is an international chain of stores specializing in renting copies of movies and video games to retail customers. VPI also sells new and used copies of these products, and offers "memberships" entitling members to unlimited use of DVDs or video games for one year (one DVD or game at a time). With over 7,000 stores worldwide (approximately 5,000 in the U.S. and 2,000 in 23 other countries), VPI is among the top two or three companies in the industry. Founded twenty years ago, it has been an audit client of your CPA firm for the past three years.

For several years, the traditional movie and video game rental industry has been saturated, and recently has been declining by an average of $4 \%$ per year as measured by industry gross margins and by $6 \%$ per year as measured by industry profits. Lately, companies in the movie rental industry have been facing stiff competition on a number of fronts. First, competing companies such as Netflix offer internet-based subscription services, taking business away from traditional stores like VPI and forcing them to discontinue charging late fees to customers, a significant source of revenues. Second, companies such as Wal-Mart, Circuit City and Best Buy have been selling new copies of both newly-released and classic DVDs at rock-bottom prices, sometimes even at a loss, also taking business away from traditional stores like VPI. Finally, many customers have turned to video-on-demand cable and satellite providers (often in conjunction with digital video recorders, or DVRs) to satisfy their desire for quality in-home movie experiences. Overall, U.S. consumer spending on in-home movie viewing has been increasing at a rate of $11 \%$ per year, though this rate is expected to slow to about $8 \%$ over the next five years.

Many of VPI's smaller competitors have been forced into bankruptcy. One of VPI's large competitors has responded to industry market pressures by discontinuing its late fee policy and starting its own online video subscription service. VPI has done the same, necessitating additional borrowing to cover the up-front costs of its online initiative. VPI's online video subscription service has been operational for one year, with revenues climbing at a somewhat slower pace than anticipated. VPI's CEO, Robert G. ("Bob") Finley, has gone to some lengths to successfully convince stock analysts that its online initiative will soon bolster VPI's bottom line significantly. In addition, VPI has announced that it is currently in talks with officials of the People's Republic of China to enter that market by opening 100 stores in that country. Opening these new stores will probably require the incurrence of additional debt or equity financing. 
Financially, VPI has recently reported earnings and even earnings growth, though earnings growth has recently dwindled, and cash flows from operations last year were negative for the first time in its history. VPI's return on equity and return on assets ratios have exceeded industry averages somewhat in recent years. Recent operating cash flow problems have made it a challenge for VPI to meet its debt payments in a timely manner, though it has not yet missed a payment. As with most companies, VPI's financial statements are the product of an accounting process involving significant estimates. In VPI's case, significant estimates involve revenue recognition, rental library amortization, write-down of obsolete inventory, and impairment of goodwill, among others. Recently, VPI's estimates have trended towards being more aggressive in terms of their impact on earnings. One member of the VPI's executive team who has very little accounting or finance skill has been heavily involved in the selection of accounting methods and the determination of accounting estimates.

VPI has a corporate mission statement and code of ethics. The code specifies that if an employee becomes aware of any improper or unethical acts on the part of others within the company, that employee is expected to report such behavior using a toll-free "alert line." VPI has a policy prohibiting retaliation against those reporting wrongdoing. Several employees indicated that they don't believe that this policy is taken seriously. One mentioned that her supervisor said he disagreed with the policy because it encourages workers to "spy on" one another. Another said his supervisor gave an employee who had recently reported an ethical violation a low performance rating because he was not seen as a "team player."

VPI's top management team has substantial personal investments in the stock of VPI. In addition, several key officers have contracts which provide for substantial bonuses in the event that some rather aggressive (relative to the industry) earnings targets are met. In most years, these earnings targets have been met, though only barely in recent years. Mr. Finley, VPI's CEO, is a charismatic and dominant personality at VPI who rarely tolerates opposing views once his mind is made up. Mr. Finley founded VPI and has been known to refer to VPI's Board of Directors as "The Board of Directed." There has been a marked increase in turnover among accounting and internal audit personnel lately, though mostly at the staff level and, to a lesser degree, the supervisory level.

In the past, VPI's relationship with your accounting firm has been generally positive, though a few "unresolved audit differences" have recently caused some concern about that relationship by members of the audit team. VPI's CEO has been pushing fairly aggressively for your audit to be completed quickly, citing the negotiations currently taking place with officials of the People's Republic of China. Also, Mr. Finley has strongly encouraged your firm to replace one of the audit seniors on the engagement with someone who "places more reasonable time demands" on VPI personnel. The Board of Directors and the Audit Committee do not seem to oppose Mr. Finley's desire for a quick audit with seniors who understand that time is money.

\section{DISCUSSION GUIDING QUESTIONS}

- What warning signs do you see of possible fraudulent financial reporting at VPI?

- What factors should VPI's external audit firm consider during its audit of VPI's financial statements, in light of the above warning signs? What impact would each warning sign have on the scope of work for the external auditor? What types of earnings manipulation schemes might these warning signs indicate?

\section{TEACHING NOTES}

The VPI case contains the following warning signs of potential fraudulent financial reporting, organized into several broad categories. These warning signs are accompanied by factors the auditors should consider, including possible earnings manipulation schemes. 


\section{Category A: Incentives and Pressures - Operating conditions in the industry threaten VPI's profitability and financial stability:}

1. VPI's traditional business of renting out movies and video games is mature and declining, as evidenced by the industry's declining margins in that segment, and by the bankruptcy of several of VPI's smaller competitors.

Auditor's considerations: This condition, especially in conjunction with both the need for additional financing for new stores in China and the largely-successful efforts by VPI's CEO to boost expectations on the part of stock analysts regarding VPI's online initiatives, may create pressure on management to manipulate earnings. Some possible earnings manipulation methods include:

A. The creation of fictitious revenue, or the premature recognition of revenue. For example, VPI could prematurely recognize membership revenues.

B. Manipulation of cost of goods sold. For example, VPI could postpone recognition of cost of goods sold.

C. Inappropriate management of earnings ${ }^{1}$ - for example, by:

a. lengthening the amortization period of its rental library;

b. postponing the recognition of goodwill impairment, of depreciation or amortization, or accrued expenses;

c. inappropriate changes in other accounting estimates, including contingent or estimated liabilities.

2. VPI's traditional business of renting out movies and video games is suffering from changes in the way consumers obtain in-home video entertainment, as evidenced by:

A. $\quad$ New competition from internet-based subscription services such as Netflix;

B. New competition from discounters and mass marketers of new DVDs, such as Wal-Mart and Circuit City, and

C. Increased competition from video-on-demand services such as cable TV and satellite TV services.

Auditor's considerations: see “auditor's considerations” under Category A, Part 1 above.

3. VPI is reporting earnings growth while it is reporting negative cash flows from operations. Further, other firms in the industry are reporting declining profits.

Auditor's considerations: see “auditor's considerations” under Category A, Part 1 above.

Category B: Incentives and Pressures - There appears to be excessive pressure on VPI's management to meet the requirements or expectations of third parties:

1. VPI's CEO has created expectations on the part of stock analysts that VPI's new online video subscription service will quickly improve VPI's earnings - a time frame that may be overly optimistic.

Auditor's considerations: see “auditor's considerations" under Category A, Part 1 above.

2. VPI has had difficulty meeting its debt obligations recently.

Auditor's considerations: see “auditor's considerations” under Category A, Part 1 above.

\footnotetext{
${ }^{1}$ The fact that VPI's accounting estimates have been more aggressive lately is consistent with, though not necessarily an indication of, inappropriate management of earnings.
} 
3. Reporting poor financial results might hinder VPI's anticipated expansion into China, either by preventing the deal with Chinese officials from closing, or by preventing the necessary financing from being obtained.

Auditor's considerations: see “auditor's considerations” under Category A, Part 1 above.

Category C: Incentives and Pressures - It appears that the personal financial situation of VPI's management is threatened by VPI's financial performance, creating an undue influence on management to manipulate earnings:

1. The top managers of VPI have sizeable personal investments in VPI stock.

Auditor's considerations: see “auditor's considerations” under Category A, Part 1 above.

2. A number of VPI's key officers have contracts that pay them significant bonuses if and when some rather aggressive earnings targets are met. The fact that these targets have been barely met in recent years suggests that earnings may have been managed or even manipulated in order to reach these targets.

Auditor's considerations: see “auditor's considerations” under Category A, Part 1 above.

Category D: Opportunities - The nature of VPI's operations provide opportunities such as the following to engage in fraudulent financial reporting:

1. Preparation of VPI's financial statements requires management to make a number of estimates that involve subjective judgments or uncertainties that, in some cases, are difficult to corroborate.

Auditor's considerations: This condition may invite management to inappropriately record transactions, resulting in fraudulent financial statements. The auditor should consider the following in addition to the inappropriate earnings management examples mentioned under Category A, Part 1 (C) above:
A. $\quad$ Utility of fixed assets (estimated useful lives, utility, salvage values);
B. Assessment of the future benefit of deferred costs;
C. Valuation of derivatives and potential hedging transactions.

2. VPI has operations in 23 countries outside the U.S., some of which are likely to have cultures and business practices different from those in the U.S.

Auditor's considerations: The auditors should consider the possibility that the business practices and environment in at least some of those countries might invite management to engage in practices such as the following, increasing the likelihood of questionable financial results:
A. Bribery of customs officials and/or foreign governments;
B. Kickbacks to distributors or agents;
C. Money laundering (either as the launderer or as the facilitator/vehicle).

Category E: Opportunities - There may be ineffective monitoring of management because of the following factors:

1. Management appears to be dominated by its CEO, Robert G. ("Bob") Finley, without the apparent presence of any compensating controls.

Auditor's considerations: Without proper oversight, Mr. Finley would be free to manipulate every aspect of VPI's operations and financial reporting. The auditor should consider the possibility of: 

A. Theft and/or bribery by (top) management;
B. Formation of management-controlled entities as paper vendors to divert VPI profits;
C. Use of VPI funds to purchase assets such as antiques or artwork for the personal benefit of (top) management;
D. Payment of unauthorized bonuses or other forms of compensation;
E. Diversion of assets or corporate opportunities to individuals in management or their families.

2. Oversight by VPI's Board of Directors and its Audit Committee of VPI's financial reporting process and its internal control may not be as effective as it needs to be, given the CEO's dominant style and his references to VPI's Board of Directors as "The Board of Directed."

Auditor's considerations: To the extent that Board or Audit Committee oversight is less than effective, this condition may be considered a pervasive risk that the financial statements have been materially misstated as a result of fraud.

\section{Category F: Opportunities: Internal control components may be inadequate, as evidenced by the following factor:}

1. Higher than normal turnover rates of accounting and internal audit staff.

Auditor's considerations: High turnover rates among such staff, especially at the supervisory level, facilitate management override of controls, and may lead to ineffective separation of duties and a poor matching of job responsibilities with professional qualifications. In addition to being alert to the previously-mentioned earnings manipulation methods, the auditor should consider the possibility of:
A. Fraudulent dealings with VPI's vendors, lending institutions or even customers. All asset valuations and liability determinations may be questionable.
B. Misappropriation of assets (e.g., management personally benefits from use of certain vendors or the sale of the entity's assets for personal gain).
C. Unauthorized employee benefits
D. Unauthorized increases in salaries or bonuses
E. Inflated employee expenses or ghost employees.

\section{Category G: Attitudes and Rationalizations:}

1. There is ineffective support and/or enforcement of the entity's whistle-blowing policy by management.

Auditor's considerations: This condition may indicate ineffective communication, implementation, support or enforcement of the entity's values or ethical standards in general by management. Management's attitude may communicate inappropriate values or ethical standards to employees.

A. These conditions could indicate a pervasive risk that the financial statements have been materially misstated as a result of fraud (fraud might not be considered an improper means of achieving the entity's financial goals).

2. There is excessive participation by nonfinancial management in the selection of accounting methods and the determination of accounting estimates.

Auditor's considerations: This condition may indicate a pervasive risk that the financial statements have been materially misstated as a result of fraud. The auditor should give special consideration to the following:

A. Capitalization of expenses;

B. Estimates used for, and the recording of, any allowance for obsolete inventory; 
C. Any allowance for doubtful accounts receivable;

D. Utility of fixed assets;

Category H: The relationship between management and our audit firm is showing strain, as evidenced by the following:

1. VPI's CEO has placed unreasonable demands upon the audit firm with respect to the completion date of the audit.

Auditor's considerations: This could be a sign of pervasive risk that VPI's financial statements are materially misstated as a result of fraud.

2. VPI's CEO has inappropriately attempted to influence the continuance of audit personnel assigned to the VPI audit.

Auditor's considerations: This could be a sign of pervasive risk that VPI's financial statements are materially misstated as a result of fraud, because this may be an attempt to get the auditor to do less work than is appropriate.

\section{SUMMARY}

In the wake of recent high-profile corporate scandals involving fraudulent financial statements (e.g., Enron Corp., Worldcom, Adelphia Communications, Tyco International Ltd. and others), there is increased concern among investors, lawmakers and the auditing profession (AICPA 2002) with the prevention and detection of fraudulent financial reporting (e.g., The Sarbanes-Oxley Act of 2002). This case, intended for use in undergraduate auditing classes, is designed to help develop students' skills at both detecting and interpreting warning signs of fraudulent financial reporting. Case facts provide general information about a large fictional chain of video stores, as well as information about the company that should raise concerns on the part of auditors about the possibility of fraudulent financial statements. Students are asked to identify the warning signs of possible fraudulent financial reporting at the company, and are asked what implications these warning signs have for the company's external auditors.

\section{REFERENCE}

1. American Institute of Certified Public Accountants (AICPA), 2002, Statement on Auditing Standards (SAS) 99: Consideration of Fraud in a Financial Statement Audit. 